\title{
Patrimônio geológico e mineiro do Quadrilátero Ferrífero, Minas Gerais - Caracterização e iniciativas de uso para educação e geoturismo
}

\author{
Geological and mining heritage of iron quadrangle, Minas Gerais - Characterization and strategies \\ for education and geotourism
}

ÚRSULA AZEVEDO RUCHKYS, MARIA MÁRCIA MAGELA MACHADO

Universidade Federal de Minas Gerais - tularuchkys@yahoo.com.br - mmarciamm@gmail.com

\begin{abstract}
Resumo
O Quadrilátero Ferrífero - QF é internacionalmente reconhecido como uma das maiores províncias minerais do planeta. Constituído por rochas que contam parte da história da Terra associada ao Arqueano e Paleoproterozoico e com vestígios de mais de 300 anos de exploração mineral contínua, especialmente de ouro e ferro, esta região se destaca por seu significativo patrimônio geológico e mineiro. Este trabalho apresenta inicialmente aspectos da geologia e da história da mineração do Quadrilátero Ferrífero. Em seguida, são descritos quinze sítios representativos da história geológica do QF que justificam a relevância de seu contexto geológico e evolução tectônica para a compreensão da história geológica da Terra. Na sequência, é descrito parte do patrimônio mineiro desta região por meio do detalhamento de onze sítios que compõem parte significativa da história da mineração no Brasil. Finalmente, são apresentadas iniciativas de educação e geoturismo realizadas na região.
\end{abstract}

Palavras-chave: Quadrilátero Ferrífero; patrimônio geológico; patrimônio mineiro; história da mineração no Brasil; geoturismo.

\begin{abstract}
The Quadrilátero Ferrífero (Iron Quadrangle) - Minas Gerais/Brazil is well-known worldwide as one of the world's largest mineral province. The region consists of rocks that show part of Earth's history associated with the Archean and Paleoproterozoic, together with remains of more than 300 years of continuous mining, particularly gold and iron. The paper initially presents a general characterization of the Iron Quadrangle, considering its geology and mining history. Then, it describes thirteen sites representatives of the geological history, highlighting the relevance of its geological context and tectonic evolution for understanding of the Earth's history. The mining heritage is also described, detailing eleven sites that compose a significant part of the mining history of in Brazil. Finally, initiatives of geotourism and education initiatives developed in the region are presented.
\end{abstract}

Key words: Iron Quadrangle; geological heritage; mining heritage; history of mining in Brazil; geotourism.

\section{INTRODUÇÃO}

O Quadrilátero Ferrífero (QF) localiza-se na porção centro-sudeste do Estado de Minas Gerais. Com área de cerca de $7.000 \mathrm{~km}^{2}$, abrange parte dos municípios de Bom Jesus do Amparo, São Gonçalo do Rio Abaixo, Barão de Cocais, Santa Bárbara, Catas Altas, Alvinópolis, Mariana, Ouro Preto, Ouro Branco, Congonhas, Jeceaba, Belo Vale, Moeda, Itabirito, Rio Acima, Brumadinho, Mario Campos, Sarzedo, Ibirité, Nova Lima, Raposos, Sabará, Caeté, Belo Horizonte e Santa Luzia (Figura 1).

Constituído por rochas que contam parte da história da Terra associada ao Arqueano e Paleoproterozoico e com vestígios de mais de 300 anos de exploração mineral que compõe grande parte a história da mineração no Brasil, esta região se destaca por seu significativo patrimônio geológico e mineiro. Suas riquezas minerais e as consequentes atividades mineiras desenvolvidas, inegavelmente, desempenharam papel fundamental na ocupação do interior do Brasil.

As buscas por metais preciosos no interland brasileiro, que se sucederam pelos séculos XVI e XVII, estão amplamente ligadas ao impacto causado pelas notícias dos enormes tesouros encontrados na América pelos espanhóis, sobretudo pela descoberta das ricas minas de prata de Cerro Potosí, em 1545. As descobertas de ouro no atual território mineiro vieram das entradas paulistanas cada vez mais freqüentes e atentas aos cascalhos e areias dos ribeirões pela experiência nas lavras do litoral.

A notícia dos primeiros descobrimentos, por volta de 1690, fez aumentar o número de expedições de exploração e os achados proliferaram rapidamente causando o primeiro grande rush minerador da história mundial. Inicialmente na região de Ouro Preto e Mariana, as famosas "Minas Gerais dos Cataguás" que incluíam jazidas como as de Itaverava, Itatiaia, Antônio Dias, Padre 
Faria, Bento Rodrigues, Ribeirão do Carmo, e logo se expandiram para Inficcionado (Santa Rita Durão), Furquim, São Caetano (Monsenhor Horta), Ouro Branco, Casa Branca, Itabira do Campo (Itabirito), Catas Altas da Noruega e muitas outras. A região de Sabará caracterizou um novo grupo conhecido como "Minas do Rio das Velhas" e incluía entre outras as ricas jazidas de Congonhas do Sabará (Nova Lima), Raposos, Santo
Antônio do Rio Acima (Rio Acima). As "Minas do Caeté" incluíam as famosas lavras de Cuiabá e Morro Vermelho. E eram tantas as minas que, em 1720, foi criada a Capitania de Minas Gerais. Ao fim das primeiras décadas do século XVIII praticamente todo o território das Minas Gerais estava ocupado, havia uma profusão de cidades e vilas em função da disseminação das lavras auríferas (Machado 2009).

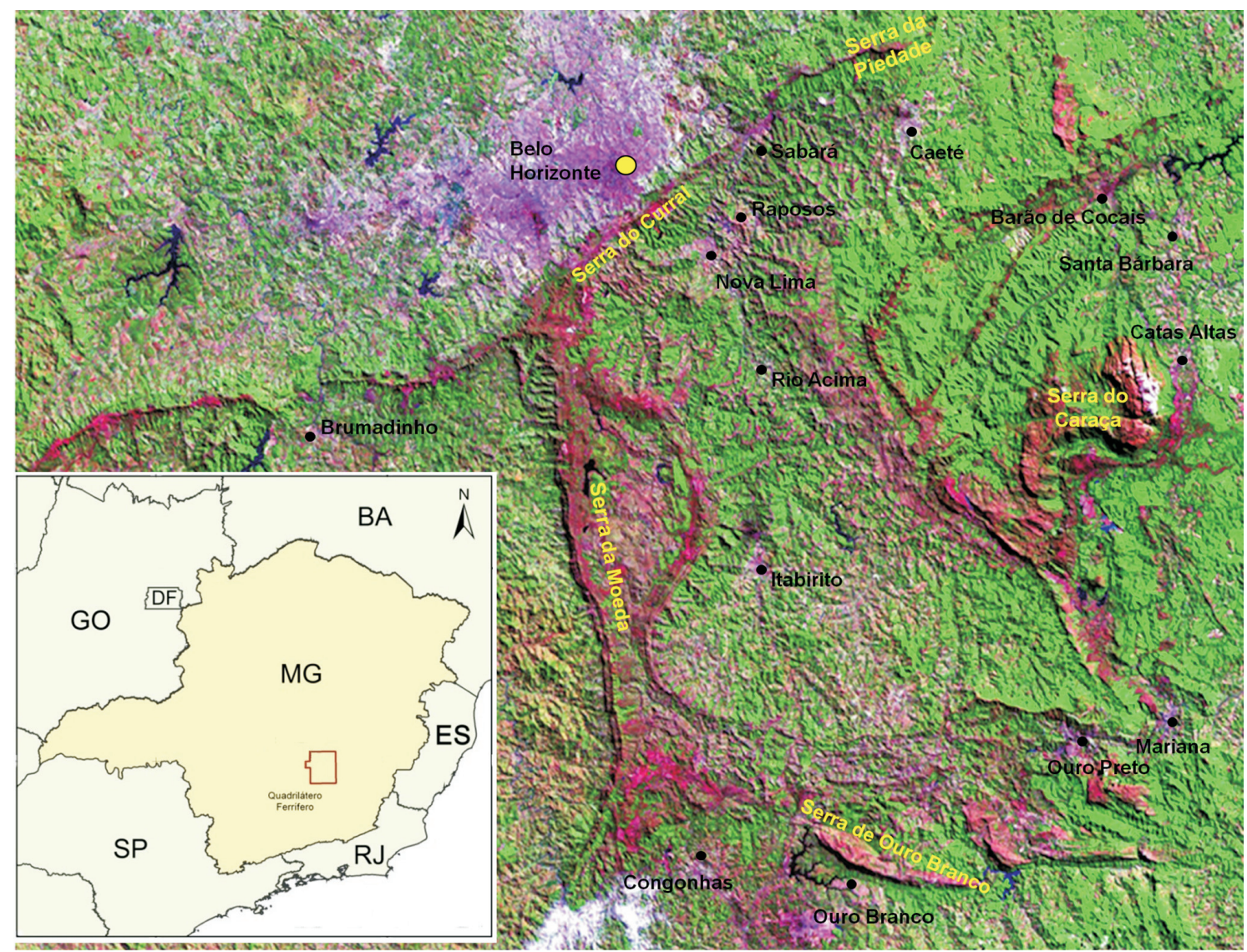

Figura 1-Mapa de localização com os municípios que integram o Quadrilátero Ferrífero.

Segundo Machado (2009), depois de aproximadamente 100 anos de atividades mineiras em profusão, o declínio acentuado da extração de ouro nas últimas décadas do século XVIII trouxe as primeiras pesquisas científicas e contribuições sobre a constituição geológica dos terrenos tendo como objetivo a descoberta de novos recursos minerais. Durante todo o século XIX a região foi palco do que havia de mais recente em termos de ciência na Europa, ao receber em seus terrenos, renomados pesquisadores estrangeiros. As observações geológicas desses naturalistas se referem, basicamente, aos mesmos lugares por força de um itinerário de interesse comum, que passava obrigatoriamente pelas famosas minas de topázio nos arredores de Ouro Preto e minas de ouro, então exploradas por companhias inglesas. Alguns desses estrageiros, com formação mais específica em Geologia, como o Barão de Eschwege, Peter Claussen, Virgil von Helmreichen, além do detalhamento das formações, produziram mapas geológicos da região, estando entre estes as primeiras representações da geologia do Brasil. Na primeira década do século $\mathrm{XX}$, a descoberta das enormes reservas de manganês e ferro colocou mais uma vez a região em evidência no cenário internacional e impulsionou novamente as atividades mineiras. Em função dessas reservas e dos limites da área bem marcados pelo relevo, a designação Quadrilátero Ferrífero foi introduzida na literatura, em 1952, numa comunicação apresentada no XVIII Congresso Internacional de Geologia. A partir daí foi disseminada de tal forma que, rapidamente, extrapolou a comunidade geológica e hoje é amplamente reconhecida e utilizada, indiscriminadamente, para citar ou se referir à região (Machado 2009).

O interesse pela área permanece até os dias atuais, não apenas pelas grandiosas reservas de minério de ferro e outras riquezas minerais existentes, como o ouro ainda explorado, mas também por serem sua 
geologia, mineralogia e geodinâmica uma das mais fascinantes do mundo.

Um reconhecimento recente está associado ao seu significativo patrimônio geológico constituído por numerosos afloramentos de rochas de excepcional interesse científico e pedagógico que permitem a compreensão dos processos de evolução da história geológica da Terra.

Liccardo (2007) salienta a importância de Minas Gerais em termos de características geológicas ligadas à história da mineração, destacando para a região do Quadrilátero Ferrífero os municípios de Ouro Preto e Mariana cuja história e turismo se confundem com a mineração e a geologia. Segundo Cesar-Mendes (2003), nestes municípios ainda pode ser visto importante patrimônio geológico/mineiro, sendo sua preservação primordial para as gerações futuras. Outros autores também registram o valor patrimonial do Quadrilátero Ferrífero, como Ruchkys et al. (2006); Silva (2007); Ruchkys (2007); Ruchkys (2009); Ruchkys et al.(2009); Machado (2009); Castro et al. (2011); Ostanello (2012) e Ruchkys et al. (2012).

Este importante patrimônio geológico e mineiro revela grande potencial para uso turístico, conforme Ruchkys (2007) e pode integrar planos de desenvolvimento regional agregando valor a produtos típicos tradicionais já existentes. Uma estratégia interessante é a proposta de criação do Geopark Quadrilátero Ferrífero apresentada pelo Governo do Estado à UNESCO, em 2009. O QF reúne os requisitos básicos de um geoparque: é uma área com longa história de exploração mineral, geologia complexa com afloramentos privilegiados, enorme biodiversidade, belas paisagens, sendo um território propício para ações baseadas na geoconservação e geoturismo.

\section{PATRIMÔNIO GEOLÓGICO-MINEIRO, GEOCONSERVAÇÃO E GEOTURISMO}

A palavra patrimônio está associada à herança, aquilo que é transmitido de geração para geração. Segundo Choay (2001) esta palavra foi requalificada por diversos adjetivos como genético, natural, cultural, entre outros, que fizeram dela um conceito nômade (Ruchkys 2007).

Gallego e García (1996) definem o patrimônio geológico como o conjunto de recursos naturais não renováveis de valor científico, cultural e educativo, incluindo as formações, estruturas geológicas, formas do terreno, os jazimentos paleontológicos e mineralógicos, que permitem reconhecer, estudar e interpretar a evolução da história geológica da Terra e os processos que tem modelado.

Para Riart (2000), o patrimônio mineiro é algo mais complexo de se definir, já que em alguns casos está associado ao patrimônio geológico, mas também se relaciona com o patrimônio cultural (arquitetônico, arqueológico, arqueológico-industrial, etc.). O mesmo é colocado por Rodrigues et al. (2011) ao afirmarem que o patrimônio mineiro nem sempre tem tido um posicionamento claro perante ao patrimônio geológico, sendo habitualmente integrado ao patrimônio industrial.

Seguindo o conceito proposto por Cordeiro (2010), o patrimônio mineiro se relaciona ao patrimônio geológico por incluir os vestígios materiais e imateriais relacionados com a atividade mineira, assim como os aspectos geológicos que promovem a exploração.

A necessidade de proteger o patrimônio geológico e mineiro tem levado ao desenvolvimento de estratégias que incluem a criação de leis para proteção deste patrimônio e iniciativas de valorização e divulgação. Cabe salientar que alguns países, principalmente europeus, dispõem de legislação específica para a proteção do patrimônio geológico. No Brasil este patrimônio vem sendo protegido de forma indireta pela criação de unidades de conservação que tem respaldo em diversos instrumentos legais relacionados às políticas públicas para a conservação da biodiversidade. Além disso, existem referências legais específicas para determinados tipos de patrimônio que integram o patrimônio geológico. Abaíde (2012), por exemplo, destaca o Art. 216 da Constituição Federal de 1988, onde no rol dos bens integrantes do patrimônio cultural brasileiro estão incluídos os sítios paleontológicos. No caso de iniciativas envolvendo valorização e divulgação merece destaque o geoturismo, que tem como uma de suas preocupações a de tornar o patrimônio geológico e mineiro acessível ao grande público, recorrendo para isso ao artifício de traduzir o significado deste patrimônio para uma linguagem comum.

O termo geoturismo passou a ser comumente utilizado a partir de meados da década de 90 depois que uma primeira definição, cunhada por Hose (1995), foi amplamente divulgada numa revista profissional de interpretação. Posteriormente, o próprio Hose (2000) definiu geoturismo como sendo:

"A provisão de facilidades interpretativas $e$ serviços para promover o valor e os benefícios sociais de lugares e materiais geológicos e geomorfológicos e assegurar sua conservação, para uso de estudantes, turistas e outras pessoas com interesse recreativo ou de lazer." (Hose 2000)

Uma definição brasileira de geoturismo foi dada por Ruchkys (2007) que apresentou a atividade como um segmento do turismo que tem o patrimônio geológico como seu principal atrativo e busca sua proteção por meio da sensibilização do turista, utilizando para isto a interpretação para torná-lo acessível ao público leigo, além de promover sua divulgação e o desenvolvimento das ciências da Terra. 


\section{ASPECTOS DA GEOLOGIA DO QUADRILÁTERO FERRÍFERO}

Para Ruchkys et al. (2006), o geoturismo oferece oportunidade para uma aproximação da geologia com o público, além de ser um novo produto de turismo direcionado a pessoas motivadas por sede conhecimento intelectual e por atividades que envolvam exploração, descoberta e imaginação. A necessidade de prover conhecimento faz a interpretação, meio eficaz de informar em linguagem acessível, ter um papel preponderante no aumento do interesse pela geologia e geoconservação, além de promover sua divulgação.
O contexto geológico do Quadrilátero Ferrífero é caracterizado por três grandes associações de litotipos: duas de idade arqueana representadas por terrenos granito-gnáissicos e por uma unidade do tipo greenstone belt (Supergrupo Rio das Velhas), e a terceira composta por uma sequência metassedimentar paleoproterozoica contendo formações ferríferas bandadas do tipo lagosuperior (Supergrupo Minas) (Figura 2). Encontram-se no Quadrilátero Ferrífero elementos geológicos representativos de parcela considerável da evolução PréCambriana.

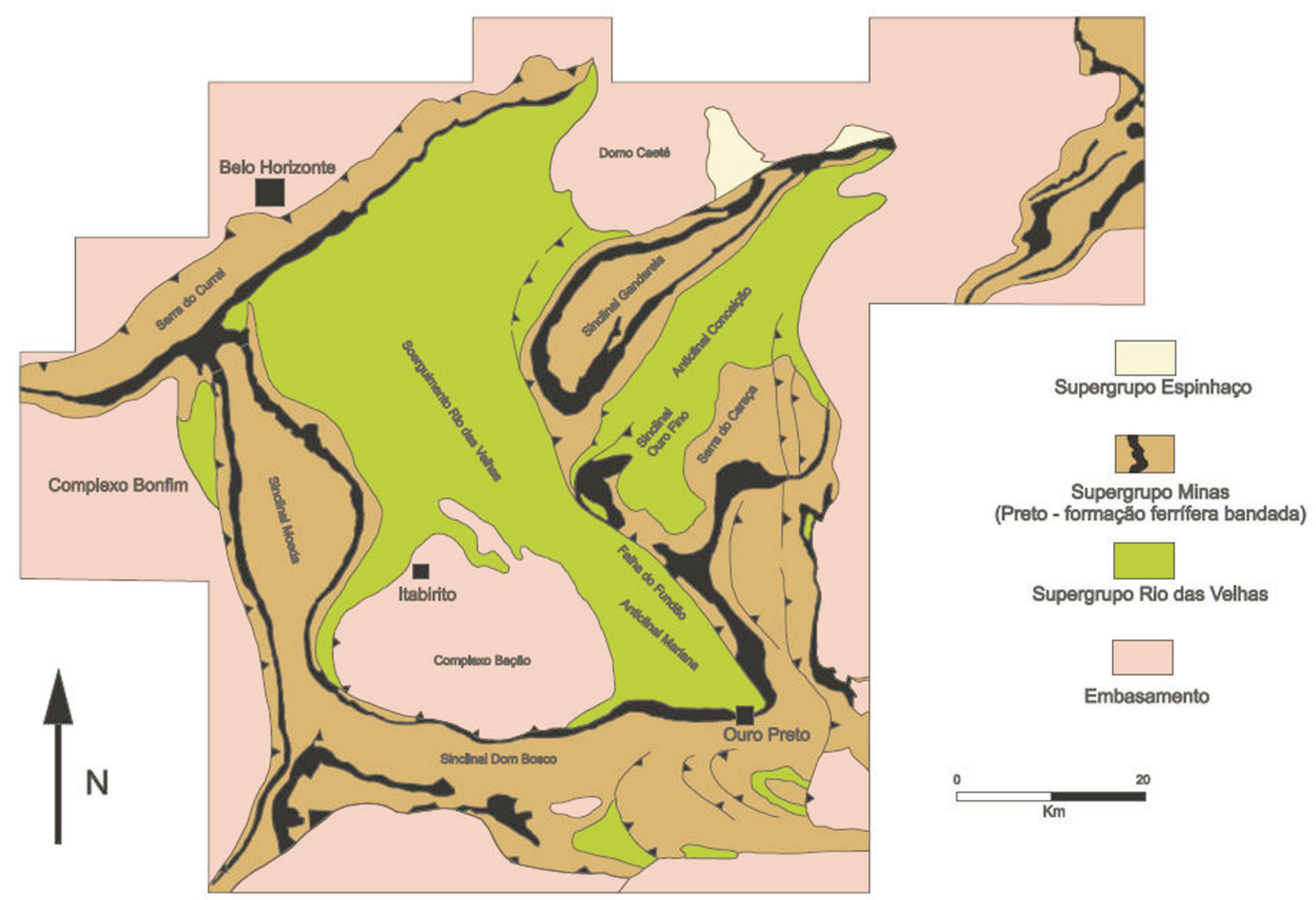

Figura 2 - Mapa geológico simplificado do Quadrilátero Ferrífero. Fonte: Alkmin \& Marshak (1998)

Os terrenos granito-gnáissicos correspondem ao embasamento cristalino e representam as rochas mais antigas da região (Ca. 2800Ma). Estas rochas distribuemse ao redor e na parte central do Quadrilátero Ferrífero, e, geralmente, apresentam estrutura dômica. Suas principais ocorrências são os complexos do Bação, Belo Horizonte, Caeté, Bonfim e Florestal (Renger et al. 1994). O Supergrupo Rio das Velhas (aproximadamente 2700Ma) corresponde a uma seqüência de rochas de origem vulcânica intercaladas com rochas de origem sedimentar e abrange os Grupos Nova Lima e Maquiné. No Grupo Nova Lima estão concentradas as ocorrências e maiores jazidas de ouro no Quadrilátero Ferrífero, responsáveis pela designação do estado como "Minas Gerais".

O Supergrupo Minas (de 2500 a 2100Ma) está dividido nos Grupos: Caraça; Itabira e Piracicaba. O Grupo Caraça apresenta as Formações Moeda e Batatal, sendo os quartzitos da Formação Moeda responsáveis pela sustentação do relevo de algumas serras do QF (como a Serra da Moeda). O Grupo Itabira apresenta as Formações Cauê e Gandarela. Na Formação Cauê estão os principais depósitos de ferro do QF. O Grupo Piracicaba é formado pelas formações Cercadinho; Fecho do Funil; Taboões e Barreiro. Ocorrem ainda no QF os Grupos Sabará e Itacolomi. O Grupo Itacolomi, cuja 
deposição se deu entre, aproximadamente, 2100 a $1750 \mathrm{Ma}$, é composto principalmente por quartzitos que estão presentes no Pico de Itacolomi, em Ouro Preto, e na Serra de Ouro Branco, em Ouro Branco.

No contexto geológico regional do Quadrilátero Ferrífero, além da sequência estratigráfica descrita anteriormente, destaca-se também a presença de rochas básicas e metabásicas intrusivas que cortam as sequências supracrustais e os terrenos granitognáissicos especialmente a oeste de Belo Horizonte e na Serra do Caraça (Alkmim \& Noce 2006).

O Fanerozoico encontra-se restrito a pequenas bacias intramontanas cenozóicas, como a bacia do Gandarela, sendo representado essencialmente por rochas pelíticas, linhitos da Formação Fonseca (Castro et al. 2001) e conglomerados compostos por clastos de itabiritos da Formação Chapada de Canga (Santana et al. 1997).

Sobre a evolução tectônica do complexo padrão do Quadrilátero Ferrífero, destaca-se o modelo proposto por Alkmin \& Marshak (1998) no qual os autores distinguem quatro fases de deformação ocorridas no QF dentro do seguinte processo de evolução: 1) Formação dos terrenos granito-greenstone arqueanos: rochas cristalinas mais antigas 3200Ma e deposição do SGRV entre 2800Ma-2700Ma; 2) Formação da bacia Minas: entre 2600-2400Ma (evento extensional); 3) Evento Transamazônico: aproximadamente em 2100Ma, a região foi envolvida por um cinturão de dobramentos e cavalgamentos com vergência noroeste; 4) Colapso orogênico transamazônico: entre 2095-2051Ma: regime extensional com desenvolvimento de terrenos em quilhas e domos; 5) Rift Espinhaço: reflexo no QF do desenvolvimento da bacia Espinhaço com a intrusão de diques de diabásio em torno de 1750Ma; 6) Brasiliano: segundo evento contracional, ocorreu entre 700-430Ma e criou um cinturão de dobramentos e cavalgamentos para oeste que reativou antigas estruturas do QF.

\section{A MINERAÇÃO NO QUADRILÁTERO FERRÍFERO}

Os recursos minerais, por constituirem insumos essenciais a praticamente todos os ramos do setor industrial e terem distribuição irregular na crosta terrestre, tem ao mesmo tempo uma enorme dimensão econômica e caráter internacional. Assim, é natural o interesse governamental em pesquisa, exploração e regulação do setor mineral. No caso específico do ouro, desde a antiguidade, esse metal adquiriu status diferenciado entre produtos comercializados. É o único metal precioso que une à facilidade para ser trabalhado, resistência à corrosão, características estéticas como beleza e brilho e ainda raridade. Estas propriedades fizeram com que o ouro começasse a ser usado na cunhagem de moedas e na produção de jóias e artefatos ainda nos primeiros séculos da antiguidade. Suas propriedades físicas, químicas e bioquímicas
garantem-Ihe hoje aplicações nas indústrias eletrônica, química, de perfumaria, textil, de impressão, papel, plásticos, produtos alimentícios, laminação de vidros, construção civil, na odontologia na medicina, entre outras (Nery \& Silva 2001).

Entretanto, é basicamente a sua capacidade de reserva de valor que o tornou tão especial. Sobretudo, para Portugal em meados do século XVII profundamente enfraquecido em termos políticos e econômicos logo após a separação da Espanha. A nação apresentava uma balança de comércio deficitária advinda dos altos custos para a reinstalação do Reino, da retração dos mercados consumidores, particularmente o do açúcar em função da concorrência da produção antilhana e da escassez de metal (Martins 1984).

O ouro brasileiro viria como remédio para esses males. Tanto que as atividades de mineração desenvolvidas no período de aproximadamente 100 anos, entre a descoberta do ouro e a exaustão do minério de fácil extração no Quadrilátero Ferrífero, têm características bem definidas em função da política mercantilista portuguesa - exploração das riquezas coloniais visando somente o abastecimento da metrópole. A lavra no Ciclo do Ouro era baseada na experiência e na observação e não em conhecimento científico, se caracterizando unicamente pela aplicação e aprimoramento de técnicas de mineração. Lavrava-se sem planejamento, produzindo montanhas de estéreis que eram depositadas muitas vezes sobre camadas ricas inviabilizando seu aproveitamento.

Primeiramente foram descobertos e minerados os depósitos nos leitos dos rios, os aluviões, onde o ouro era encontrado misturado aos seixos, areia, argila. A crescente escassez dos cascalhos ricos, facilmente acessíveis, alterou não só os trabalhos nos leitos dos rios como levou os mineiros a buscar os depósitos de aluvião nas margens ou "tabuleiros", e sob uma camada não muito espessa de terra nas encostas dos morros, as "grupiaras". Nas encostas era usado o método conhecido como "talho aberto". A mineração subterrânea só acontecia diante da impossibilidade de exploração do filão rico a céu aberto, uma vez que o serviço era muito penoso e arriscado. As galerias eram estreitas e sinuosas, escavadas acompanhando a formação do veio, e chegavam a atingir centenas de metros, somente nas partes mais ricas eram alargadas. Os morros eram perfurados de um lado para o outro sem o menor planejamento ou controle, assim aconteceu em Ouro Preto, Mariana e outros localidades.

A sede de enriquecimento rápido, o total despreparo com relação ao conhecimento da estrutura das jazidas, aliada a falta de orientação ou fiscalização por parte da metrópole, pelo contrário, a imposição do oneroso quinto sobre o ouro fizeram com que o modo de minerar no ciclo do ouro funcionasse como algoz da mina. A exploração do ouro entrou em acentuado declínio a partir dos anos 60 do século XVIII. 
Logo depois da independência, aproveitando a legislação brasileira favorável à entrada de capital estrangeiro para o desenvolvimento da atividade de mineração, começaram a chegar os ingleses. Nos anos 1820 e 1830 foram formadas na Inglaterra seis companhias para explorar ouro em Minas Gerais.

As Companhias inglesas trouxeram mudanças significativas em todos os estágios de produção de ouro, introduziram o emprego da pólvora e mais tarde da dinamite, amalgamação por mercúrio e a utilização generalizada de força hidráulica nas operações de drenagem, ventilação e transporte (com vagonetes e caçambas movidos por roda d'água), e engenhos hidráulicos de redução do minério os quais foram responsáveis pelos maiores ganhos de produtividade. Apesar de terem obtido o controle das melhores jazidas, as companhias inglesas suavizaram o ritmo, mas não reverteram a tendência de queda do setor aurífero, pelo menos em termos de quantidade produzida até 1860 . A produção anual média que havia sido $1.884 \mathrm{Kg} \mathrm{em}$ $1801 / 1820$, caiu para $1.602 \mathrm{Kg}$ em 1820/1860, dos quais, aproximadamente, $52 \%$ foram extraídos em Gongo Soco, Morro Velho e Cata Branca (Martins 1989).

Em fins do século XIX começaram a aparecer os reflexos do apelo capitalista por minerais industriais como carvão, petróleo, ferro e manganês. Com a intensificação e diversificação do processo de industrialização pós-Primeira Guerra e consequente aumento da demanda por combustível e matéria-prima, as riquezas minerais do Quadrilátero Ferrífero se tornaram, mais uma vez, o centro das atenções, desta feita, o manganês e o ferro. No início dos 1900 o interesse dos países produtores de aço, principalmente a Inglaterra, pelas jazidas de manganês e ferro de Minas Gerais já era patente. Entre 1905 e 1920 houve uma intensa aquisição de jazidas de minério de ferro por estrangeiros. A constituição republicana de 1891 havia aberto esta prerrogativa. No que se refere ao direito de propriedade das minas, o chamado sistema dominial vigente durante o Império, no qual o subsolo pertence à nação, foi substituído pelo sistema norte-americano, submetendo a propriedade das minas à da superfície (Machado 2009).

$\mathrm{Na}$ década de 30, com as mudanças introduzidas pela promulgação do Código de Minas do país, entre elas a necessidade de autorização do governo da União para pesquisa e lavra e somente para cidadãos brasileiros ou empresas organizadas no Brasil, as companhias estrangeiras que exploravam o minério de ferro no Quadrilátero Ferrífero, passaram por um processo de nacionalização.

Em 1946, por ordem constitucional, a mineração em território brasileiro foi reaberta à participação de capital estrangeiro, em 1988 foram restabelecidas as restrições e, finalmente, em 1995, os impedimentos ao capital externo foram novamente suprimidos. Hoje o Quadrilátero Ferrífero é responsável por cerca de $60 \%$ do minério de ferro exportado pelo Brasil que, em 2011, atingiu a marca de 331 milhões de toneladas de uma produção da ordem de 390 milhões. De acordo com a Secretaria do Comércio Exterior -SECEX, do Ministério do Desenvolvimento, da Indústria e do Comércio Exterior, em 2011, o minério de ferro permaneceu liderando a pauta das exportações nacionais. A Companhia Vale do Rio Doce é, destacadamente ,a principal exportadora brasileira de minério de ferro, com $79 \%$ do total das exportações (Sinferbase 2011).

Existem ainda no Quadrilátero Ferrífero ocorrências de urânio, prata, arsênio, enxofre, bário, topázio imperial, talco, serpentina, agalmatolito, calcário, dolomito, quartzo, caulim, grafita, rochas ornamentais, areia, argilas, entre outras.

\section{PATRIMÔNIO GEOLÓGICO DO QUADRILÁTERO FERRÍFERO}

As rochas que afloram no Quadrilátero Ferrífero datam do Arqueano e Paleoproterozoico que, juntamente com o Hadeano (intervalo que marca os primórdios de formação do planeta), ocupam cerca de 8/10 da história da evolução da Terra. Nesta época a Terra esteve submetida a diversos eventos como vulcanismo, tectonismo, mudanças na atmosfera, hidrosfera, biosfera e nos sistemas de sedimentação. Registros destes eventos estão preservados nos diferentes conjuntos de rocha do Quadrilátero Ferrífero: complexos metamórficos de rochas cristalinas arqueanas; sequências do tipo greenstone belts arqueana representada pelo Supergrupo Rio das Velhas e sequências metassedimentares paleo e mesoproterozoicas representadas pelo Supergrupo Minas, Grupo Sabará e Grupo Itacolomi. Assim, para apresentação desse patrimônio geológico foram selecionados sítios de diferentes unidades geológicas com base nas descrições de Ruchkys et al. (2006); Ruchkys (2007); Ruchkys (2009); Ruchkys et al. (2009) e Ruchkys et al. (2012).

\subsection{GNAISSE DE CACHOEIRA DO CAMPO}

É um sítio de interesse regional do ponto de vista científico e educativo e está localizado no distrito de Cachoeira do Campo. O embasamento cristalino granitognáissico-migmatítico de composição tonalitotrondhjemito-granodiorito (TTG) corresponde às rochas mais antigas do Quadrilátero Ferrífero, sendo a base de todas as unidades geológicas desta região. Os gnaisses de composição TTG, juntamente com sequências do tipo greenstone belt, são os constituintes mais característicos dos crátons arqueanos. As primeiras crostas continentais da Terra e os primeiros núcleos protocratônicos que começaram a se formar em quatro bilhões de anos eram compostos por gnaisses desse tipo. No Quadrilátero 
Ferrífero o embasamento cristalino é dividido em complexos que recebem denominações locais diferentes: Complexo Bação; Complexo Bonfim; Complexo Belo Horizonte; Complexo Caeté; Complexo Santa Bárbara. O sítio do gnaisse de Cachoeira do Campo (Figura 3) encontra-se no Complexo Bação.

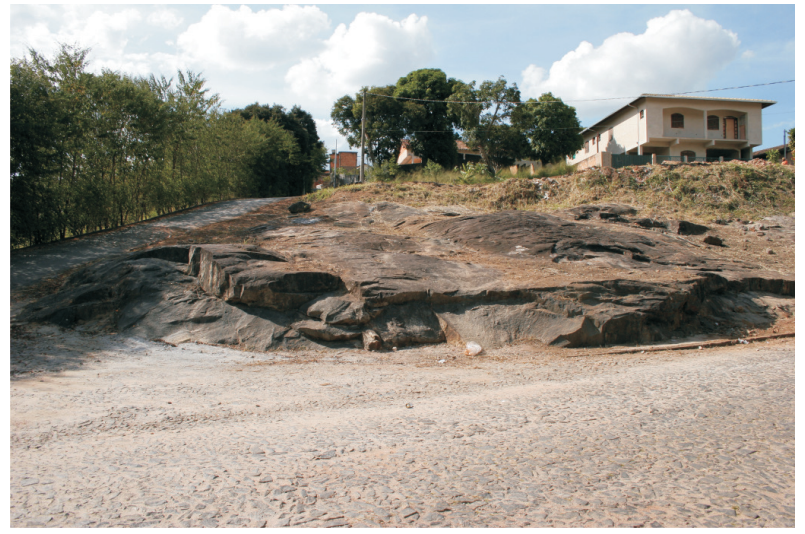

Figura 3 - Visão geral do gnaisse de Cachoeira do Campo no Complexo Bação. Fonte: acervo CPRM

\subsection{METAVULCÂNICAS DO SUPERGRUPO RIO DAS VELHAS}

É um sítio de interesse regional do ponto de vista científico e educativo. Trata-se de rocha metaultramáfica serpentinizada e xistificada da base do Supergrupo Rio das Velhas, representado por sucessões sedimentares e de rochas vulcânicas depositadas no Quadrilátero Ferrífero entre 2800-2700 Ma que contém importantes depósitos de ouro (Figura 4). O desenvolvimento do Supergrupo Rio das Velhas caracterizou um evento de crescimento da crosta continental formando uma plataforma relativamente grande.

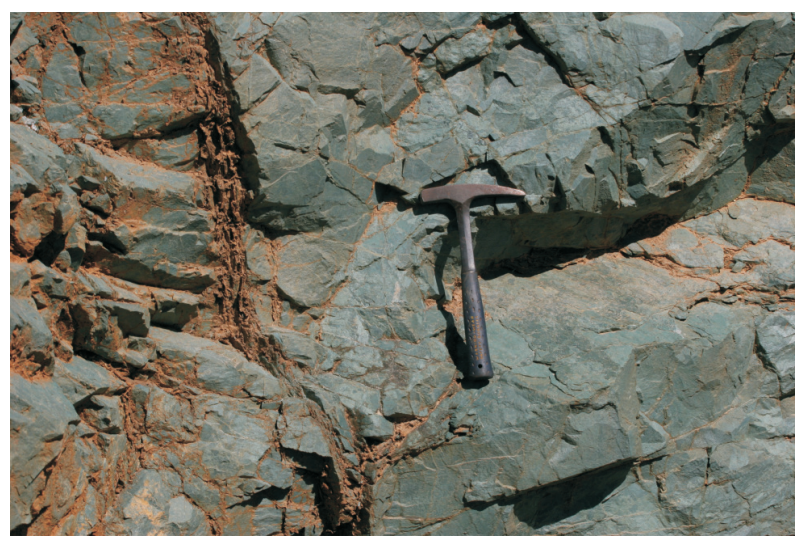

Figura 4 - Afloramento de rocha metaultramáfica serpentinizada da base do Supergrupo Rio das Velhas. Fonte: Dionisio Tadeu de Azevedo

\subsection{META-ARENITOS DA SERRA DO ANDAIME}

Sítio de interesse regional do ponto de vista científico e educativo. Este sítio está localizado no município de Itabirito na Serra do Andaime e está relacionado ao Grupo Maquiné e o Supergrupo Rio das Velhas. Os meta-arenitos da Serra do Andaime são interpretados por Pedreira (1995) e Baltazar \& Pedreira (2000) como uma associação litorânea originados em ambiente marinho raso no Arqueano, sendo, portanto, o registro de uma das primeiras praias do Brasil. Os afloramentos indicam as litofácies desse ambiente: água rasa com influência de maré e dunas costeiras (Figura 5).

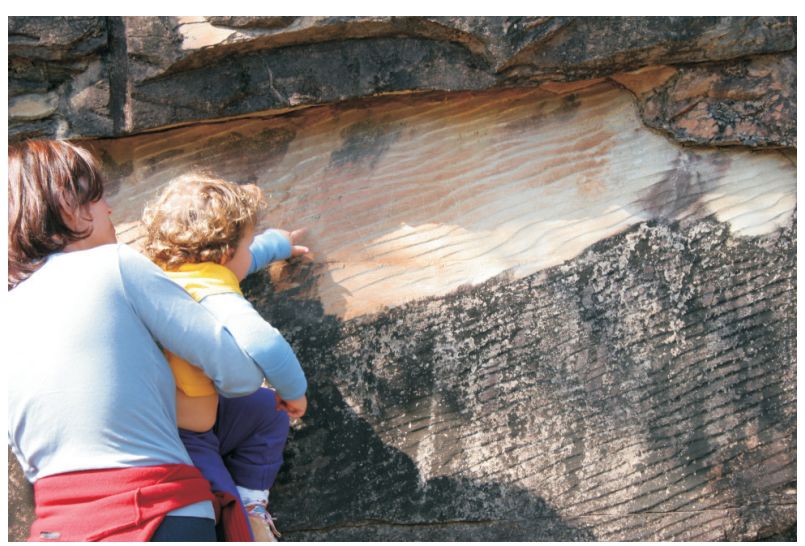

Figura 5 - Detalhe de marcas de onda nos meta-arenitos da Serra do Andaime. Fonte: Dionisio Tadeu de Azevedo.

\subsection{QUARTZITOS E CONGLOMERADO BASAL DA FORMAÇÃO MOEDA-SERRA DA MOEDA}

Sítio de interesse nacional do ponto de vista científico, educativo, estético, cultural e turístico. O sítio está localizado na Serra da Moeda, cerca de $20 \mathrm{~km}$ ao sul de Belo Horizonte. Em um contexto de relativa quiescência global e existência de uma plataforma arqueana recém-consolidada, foi implantada a protobacia Minas com sedimentação inicialmente continental e posteriormente marinha. O Supergrupo Minas começou a se depositar em aproximadamente 2500Ma, ao longo de uma bacia de margem passiva desenvolvida na plataforma continental preexistente. O primeiro registro da abertura dessa bacia é marcado pelos metaconglomerados auríferos e uraniníferos que se encontram na parte basal da Formação Moeda. A sequência é constituída ainda por quartzito que sustenta a Serra da Moeda (Figura 6). 


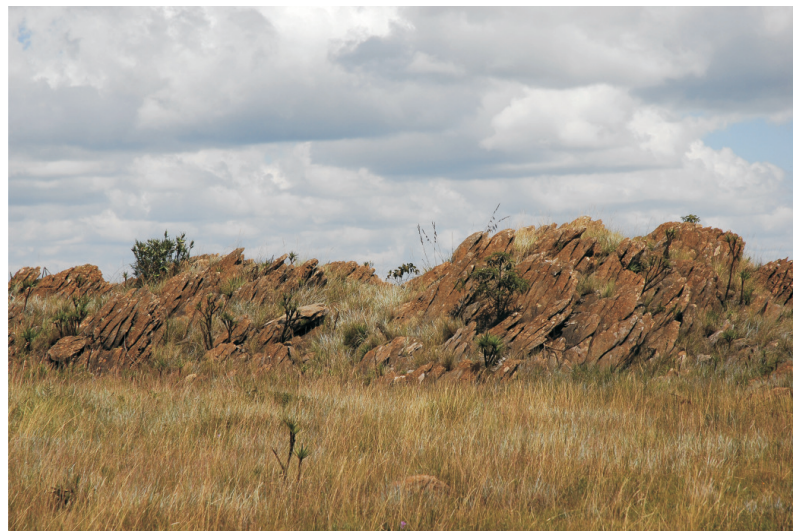

Figura 6 - Afloramento de quartzito da Formação Moeda na serra homônima.

\subsection{SANTUÁRIO DA SERRA DO CARAÇA}

Sítio de interesse internacional do ponto de vista científico, educativo, estético, cultural, religioso, histórico e turístico, reconhecido pelo SIGEP como patrimônio geológico do Brasil. Serra do Caraça é o nome genérico para um conjunto de montanhas que abriga as maiores altitudes do Quadrilátero Ferrífero, com Pico do Sol atingindo 2.072 metros de altitude (Figura 7). É composta essencialmente por quartzitos da Formação Moeda do Grupo Caraça, com ocorrência de cavernas entre as quais se destaca a Gruta do Centenário, a maior do mundo nesta litologia. Seus condutos formam uma rede labiríntica quadrática atingindo $481 \mathrm{~m}$ de desnível e $3.790 \mathrm{~m}$ de projeção horizontal $(4.700 \mathrm{~m}$ de desenvolvimento linear). Hoje, o Caraça é uma Reserva Particular do Patrimônio Natural (RPPN).

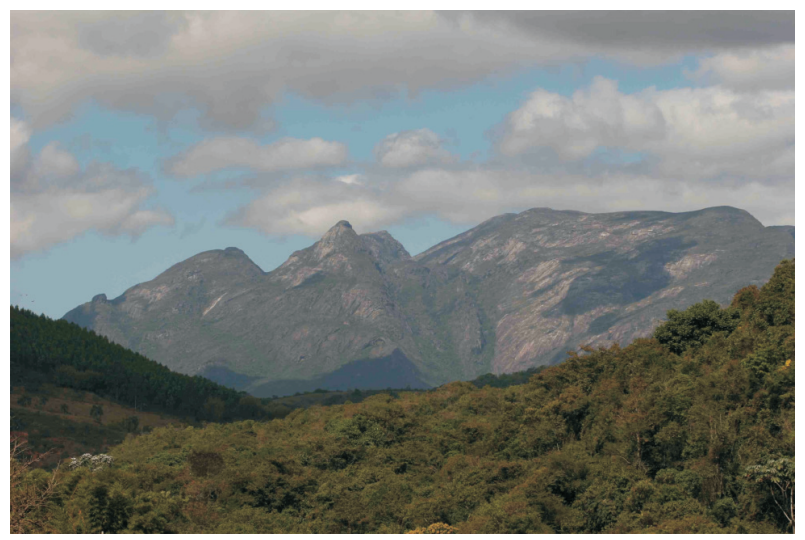

Figura 7 - Vista geral da Serra do Caraça. Foto: Dionisio Tadeu de Azevedo.

\subsection{SERRA DA PIEDADE}

Sítio de interesse internacional do ponto de vista científico, educativo, estético, cultural, religioso, histórico e turístico. Com expressivos afloramentos de BIF's (Banded Iron Formation) regionalmente conhecidas como itabiritos (Figura 8), a Serra da Piedade foi reconhecida pelo SIGEP como patrimônio geológico e paleontológico do Brasil, descrita por Ruchkys et al. (2009). Além da importância geoecológica para compreensão dos fenômenos que levaram à evolução da vida dos oceanos e da atmosfera no Pré-Cambriano, os itabiritos apresentam grande importância econômica. No Quadrilátero Ferrífero, há várias minas de ferro hospedadas dentro de formações ferríferas bandadas onde a lixiviação de minerais de ganga (principalmente quartzo e dolomita) promoveu o enriquecimento residual de ferro na rocha.

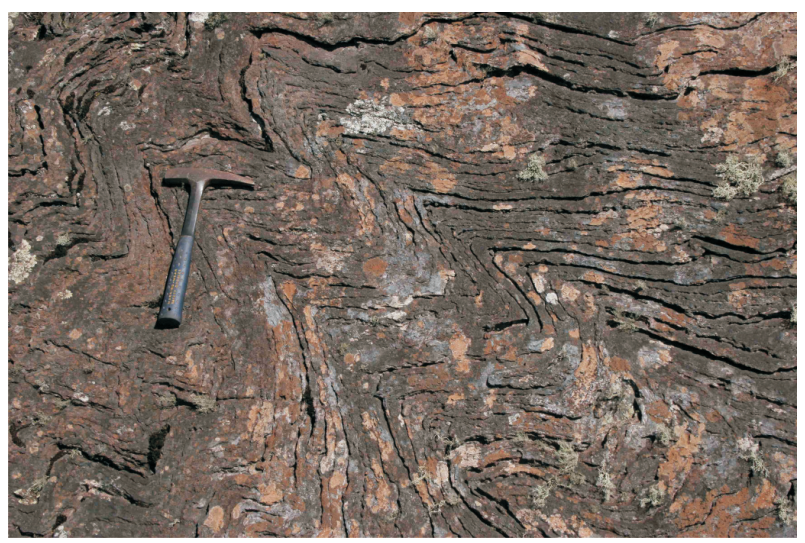

Figura 8 - Afloramento de itabirito dobrado na Serra da piedade. Foto: Dionisio Tadeu de Azevedo.

\subsection{SERRA DO CURRAL}

Sítio de interesse nacional do ponto de vista científico, educativo, estético, cultural, histórico e turístico. A serra do Curral corresponde a um homoclinal, cujo eixo se orienta, em linhas gerais, de NE para SW, constituindo o limite norte do Quadrilátero Ferrífero. Afloram na Serra do Curral parte da seqüência metassedimentar do Supergrupo Minas: grupos Caraça, Itabira e Piracicaba. Essas unidades apresentam inversão estratigráfica ocasionada pela tectônica e caracterizam uma diversidade litoestrutural e morfológica e um relevo acidentado. A Serra do Curral tem seu nome associado ao antigo Curral Del Rey, arraial que se desenvolveu em sua base e que daria lugar a atual cidade Belo Horizonte. 


\subsection{SINCLINAL DO GANDARELA}

Sítio de interesse regional do ponto de vista científico e educativo. Caracterizado pela ocorrência de carbonatos, um dos indícios da mudança paleoambiental - a dissolução dos gases atmosféricos nas águas conduz à formação do ácido carbônico $\left(\mathrm{H}_{2} \mathrm{CO}_{3}\right)$ que é fixado sob a forma de carbonato de cálcio ou de magnésio (Figura 9).

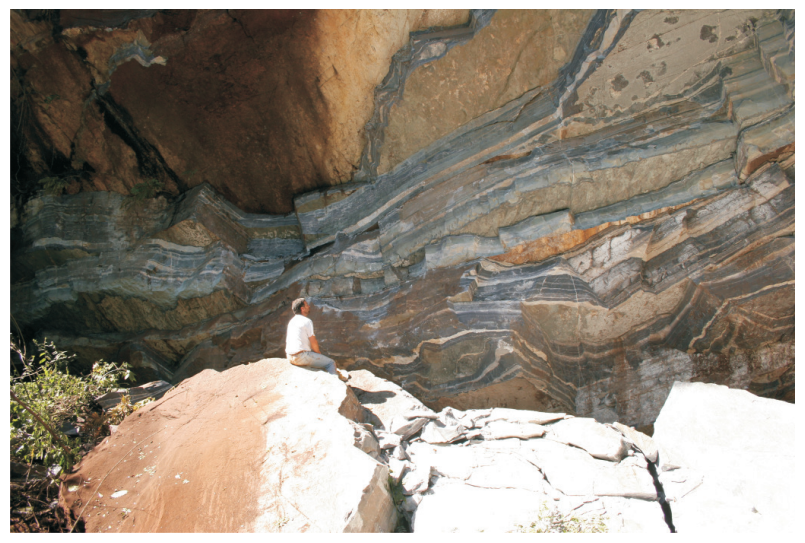

Figura 9-Visão geral de afloramento de mármore da Formação Gandarela. Foto: Úrsula Ruchkys.

\subsection{PEDREIRA DO CUMBI}

Sítio de interesse regional do ponto de vista científico e educativo. Carbonato rico em estruturas sedimentares resultantes da atividade de cianobactérias - os estromatólitos (Figura 10). Os estramatólitos précambrianos, além de ser a evidência indireta mais antiga de vida, constituem um importante registro de mudanças climáticas, paleogeográficas e ambientais.

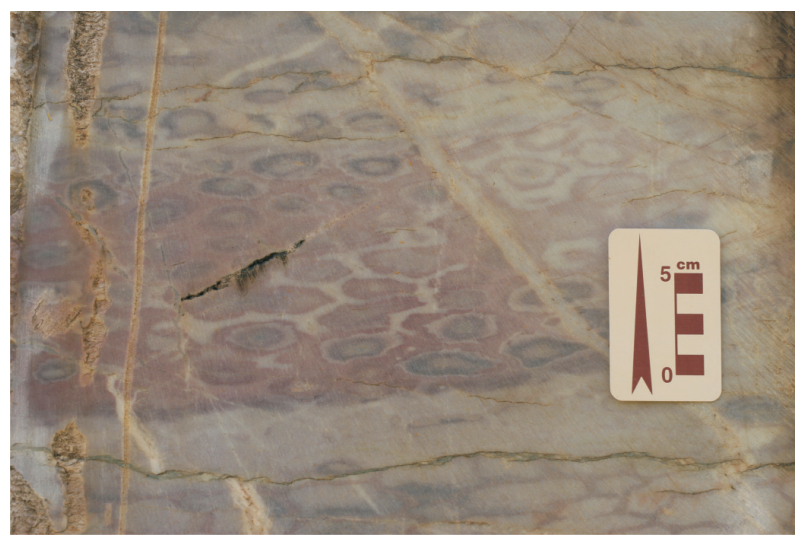

Figura 10-Detalhe dos estromatólitos preservados na Pedreira do Cumbi. Foto: Dionisio Tadeu de Azevedo.

\subsection{PICO DO ITACOLOMI}

Sítio de interesse internacional do ponto de vista científico, educativo, estético, cultural, religioso, histórico e turístico (Figura 11). O Grupo Itacolomi tem sua importância global associada ao registro do ciclo orogênico no Quadrilátero Ferrífero, fase extencional do Evento Transamazônico. Representa uma deposição típica de ambiente fluvial entrelaçado e leques aluviais em bacias intermontanas estreitas. Os leques aluviais são feições deposicionais que ocorrem tipicamente adjacentes às áreas montanhosas.

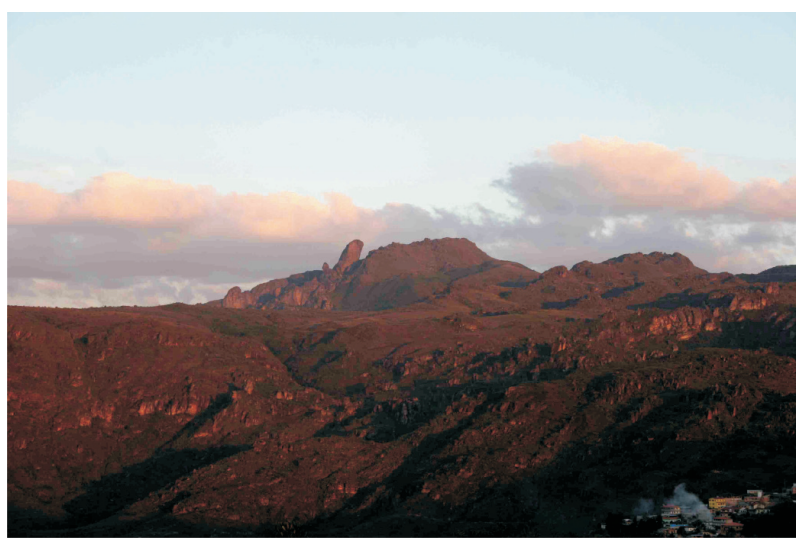

Figura 11 - Vista geral do pico do Itacolomi a partir da cidade de Ouro Preto. Foto: Dionisio Tadeu de Azevedo.

\subsection{SERRA DE OURO BRANCO}

Sítio de interesse regional do ponto de vista científico, educativo, estético, cultural, histórico e turístico, tendo sido tombada pelo Instituto Estadual do Patrimônio Histórico e Artístico de Minas Gerais - IEPHA. A Serra de Ouro Branco, a exemplo do Pico do Itacolomi, tem sua importância associada ao ciclo orogênico. A evolução do QF proporcionou uma estruturação dômica marcada por diversos sinclinais e anticlinais distribuídos pelos compartimentos que o constituem tornando possível a observação, em campo, de contrastes muito bruscos na topografia, principalmente em trechos onde movimentos tectônicos provocaram fortes desnivelamentos. A Serra de Ouro Branco permite o entendimento desta relação entre as cotas altimétricas e as características litológicas e estruturais da região assim como disponibiliza excepcionais afloramentos de quartzitos do Grupo Itacolomi. É um marco paisagístico que materializa o limite meridional do QF no sentido W-E, tendo sido descrito sob o nome de Serra do Deus-TeLivre, invariavelmente, por todos os naturalistas estrangeiros que estiveram na região nos três primeiros quartéis do século XIX (Figura 12). É formada por um paredão com cerca de $20 \mathrm{~km}$ de extensão, tendo em seu topo um planalto cuja altitude varia entre 1.250 e 1.568 metros. Possui belos mirantes e muitas cachoeiras. 


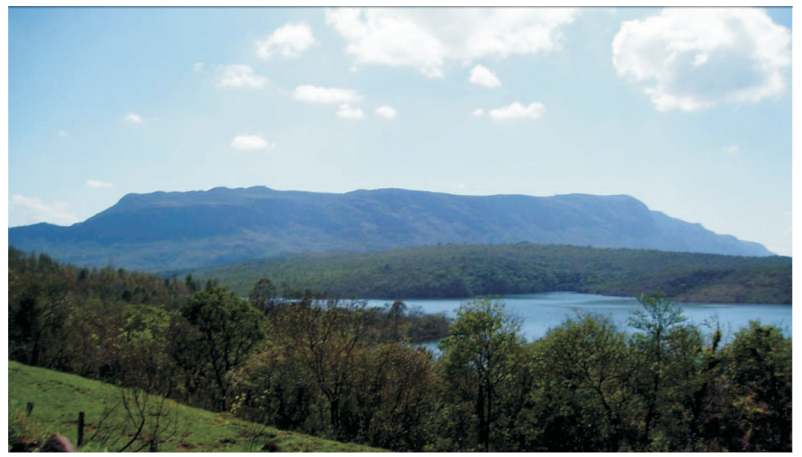

Figura 12 - Vista geral da Serra de Ouro Branco suportada por quartzitos do Grupo Itacolomi. Foto: Maria Márcia Magela Machado.

\subsection{SÍTIO PALEONTOLÓGICO DE FONSECA}

Sítio de interesse nacional do ponto de vista científico. A bacia de Fonseca, descrita por Mello et al. (2002), foi reconhecida pelo SIGEP como patrimônio geológico e paleontológico do Brasil. Constitui um clássico exemplo de sedimentos paleógenos, tendo despertado o interesse de vários pesquisadores, desde a segunda metade do século passado, por conter depósitos de "canga", linhito e sedimentos fossilíferos. 0 registro fossilífero da Formação Fonseca é caracterizado por uma grande variedade de famílias de Angiospermas, sendo as famílias Melastomataceae e Mimosaceae as mais abundantes. O fóssil mais notável pertence à Família Bombacaea - uma flor, relativamente bem conservada, apresentando a impressão das pétalas e androceu (órgão reprodutor masculino).

\subsection{SERRA DO ROLA MOÇA}

Sítio de interesse internacional do ponto de vista científico, educativo, estético, cultural, histórico e turístico. O Parque Estadual da Serra do Rola Moça apresenta boas exposições de carapaça laterítica ferruginosa, regionalmente conhecida como canga, cuja formação se deve ao processo de intemperismo do itabirito (Figura 13). Os processos de laterização e a conseqüente formação de canga são relativamente recentes, estando comumente relacionados a processos de aplainamento do relevo gerados pela atuação de processos erosivos. No caso das cangas do Quadrilátero Ferrífero, vários autores associam a formação de lateritas ao desenvolvimento da superfície de aplainamento SulAmericana, considerada Paleógena por King (1956).

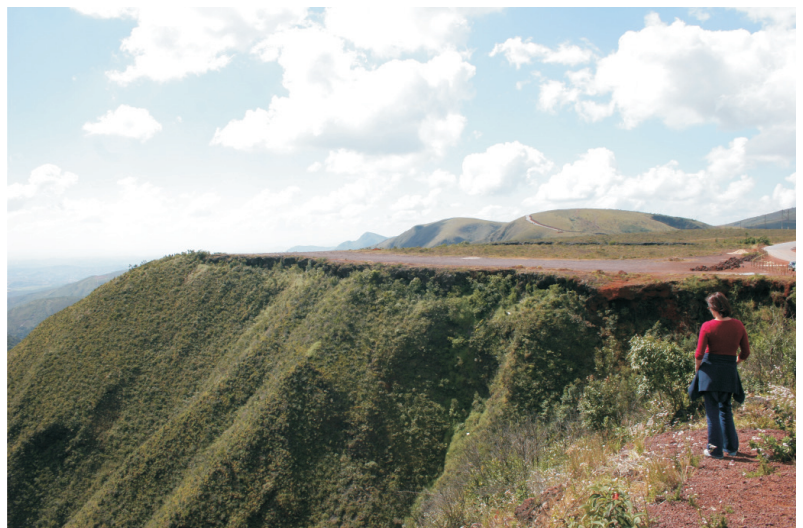

Figura 13 - Exposição de canga na Serra do Rola Moça. Foto: Dionisio Tadeu de Azevedo.

\section{PATRIMÔNIO MINEIRO DO QUADRILÁTERO FERRÍFERO}

Com cerca de trezentos anos de atividade extrativa mineral contínua, o Quadrilátero Ferrífero possui um importante espólio mineiro advindo principalmente da exploração do ouro e do ferro. A mineração deixou também um importante legado patrimonial imaterial ligado à identidade e a memória das populações mineras. Parte do patrimônio mineiro do QF é descrito a seguir, com base em Ruchkys et al.(2006); Ruchkys (2007); Ruchkys (2009) e Ruchkys et al. (2012) e Machado (2009), a partir de sítios representativos de diferentes períodos da história da mineração.

\subsection{RUÍNAS DA CASA DE FUNDIÇÃO CLANDESTINA DE OURO}

Sítio de interesse regional do ponto de vista histórico, educativo e turístico. O sítio da falsa casa de fundição do Paraopeba é de extrema importância para história da mineração, sendo um exemplo dos descaminhos do ouro no Período Colonial. A fundição clandestina de ouro é um exemplo das múltiplas táticas de fraude desenvolvidas no Período Colonial, principalmente no período do estabelecimento das primeiras Casas de Fundição oficiais entre 1724 e 1735. Montada por Inácio de Souza Ferreira, juntamente com Manuel Francisco e outros cúmplices, em um sítio estratégicamente posicionado, esta fundição cladestina produzia barras de ouro e moedas com cunhos legítimos, furtados das casas de fundição e dados como inutilizados (Figura 14). 


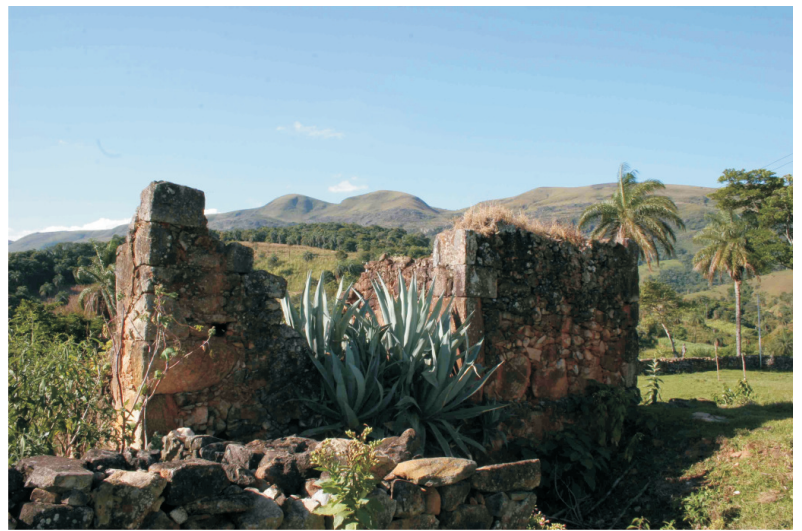

Figura 14 - Ruínas da casa de fundição clandestina no vale do Paraopeba. Foto: Úrsula Ruchkys de Azevedo.

\subsection{FÁBRICA PATRIÓTICA}

Sítio de interesse nacional do ponto de vista histórico, científico e educativo. Assim como a mineração, a siderurgia também marca a vocação da região do Quadrilátero Ferrífero.

O ferro era produzido no Brasil, desde o início da colonização, em pequenas forjas que produziam por métodos primitivos e, quase que exclusivamente, por força braçal.

Com a necessidade de suprir as demandas da mineração um decreto baixado em 1801 revogou o Alvará de 1785 que proibia a existência de fábricas na colônia, liberando a fabricação de ferro em escala industrial. Entretanto, o impulso para criação de fábricas de ferro só veio em 1808 com a elevação do Brasil a sede do Reino. A "Fábrica Patriótica", instalada pelo alemão Barão de Eschwege em Congonhas do Campo, produziu ferro pela primeira vez em 12 de dezembro de 1812 e funcionou até por volta de 1822. Foi o primeiro estabelecimento a produzir ferro em escala industrial no Brasil. O conjunto das ruínas da Fábrica Patriótica é preservado pelo IPHAN como testemunho histórico da indústria siderúrgica do Brasil (Figura 15).

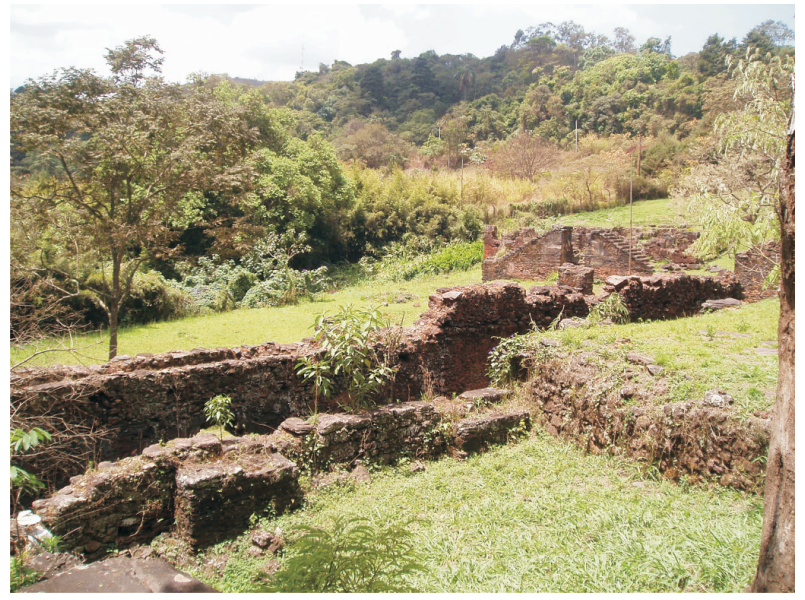

Figura 15 - Ruínas da Fábrica Patriótica. Foto: Úrsula Ruchkys de Azevedo.

\subsection{MINA DE MORRO VELHO}

Sítio de interesse internacional do ponto de vista científico, educativo, cultural, histórico e turístico. Em Morro Velho, antiga freguesia de Nossa Senhora do Pilar de Congonhas (hoje Nova Lima), a exploração do ouro remonta ao período colonial, tendo se iniciado por volta de 1725. A mina, ao longo de sua existência, experimentou a evolução nas técnicas de mineração do ouro e foi nos anos 1920 a mina mais profunda do mundo e a mais produtiva do Brasil tornando-se um referencial para a história da mineração. A mina foi paralisada em outubro de 2003 e está atualmente no processo de descomissionamento. A administração mantém, desde 1994, o Centro de Memória Morro Velho, aberto ao público, onde é resgatada a história da mineração do século XIX com grande acervo de peças e documentos históricos.

\subsection{HONÓRIO BICALHO}

Sítio de interesse regional do ponto de vista educativo, cultural e histórico. A descoberta do ouro no Rio das Velhas e no Ribeirão de Macacos levou ao desenvolvimento de Honório Bicalho, atual distrito de Nova Lima. A localidade experimentou grande prosperidade até fins dos 1700 , quando a fadiga da mineração do ouro, impôs à região uma decadência que só começou a ser revertida depois de praticamente um século com a entrada de capital estrangeiro. Depois das tentativas fracassadas de exploração por parte da Societé de Mines D'or de Faria, de capital francês, e da inglesa Faria Gold Mining Company of Brazil Limited, em 1908 a empresa inglesa Saint Jonh Del Rey Mining Company adquiriu o espólio da mina do Faria, filão mais rico, e a região voltou a se desenvolver (Figura 16). A localidade passou a ser conhecida pelo nome da estação ferrroviária - Honório Bicalho, inaugurada em 1890, assim batizada em homenagem ao engenheiro responsável pela construção do trecho.

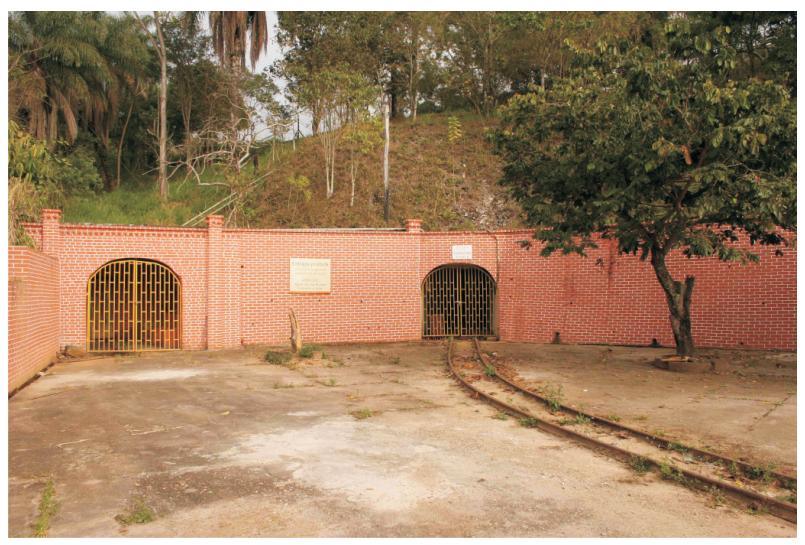

Figura 16 - Entrada da mina de ouro do Faria atualmente desativa em Honório Bicalho. Foto: Úrsula Ruchkys de Azevedo. 


\subsection{MORRO DA QUEIMADA}

Sítio de interesse nacional do ponto de vista histórico, científico e turístico, onde são encontrados construções e galerias de minas relacionadas à extração de ouro. O Morro da Queimada abrigou um dos primeiros núcleos populacionais de Vila Rica, hoje cidade de Ouro Preto. Passou a ser chamado de Morro da Queimada após ser incendiado a mando do então governador, Conde de Assumar, em represália à revolta liderada por Felipe dos Santos contra a proibição de circulação de ouro em pó e a criação das casas de fundição para arrecadação do quinto do ouro em 1720. Hoje, a região do Morro da Queimada está sendo transformada em um parque arqueológico, sendo responsável por essa iniciativa o Instituto do Patrimônio Histórico e Artístico Nacional - IPHAN.

\subsection{MINA DE CHICO REI}

Sítio de interesse internacional do ponto de vista científico, educativo, cultural, histórico e turístico. A Mina de Chico Rei é uma escavação artesanal subterrânea que se estende sob a cidade de Ouro Preto por aproximadamente 11.500 metros, distribuídos em vários níveis (Figura 17). Seus primeiros 50 metros, que seguem até o chamado salão de cristais, um átrio a partir do qual sai um tunel mais elevado, estão iluminados e abertos à visitação turística. O nome tem origem na história de Chico Rei, personagem real que segundo a tradição oral, foi trazido do Congo como escravo e trabalhou na exploração do ouro até comprar sua carta de alforria e, depois, sua própria mina. Atualmente a mina está sendo mapeada por estudantes de geologia.

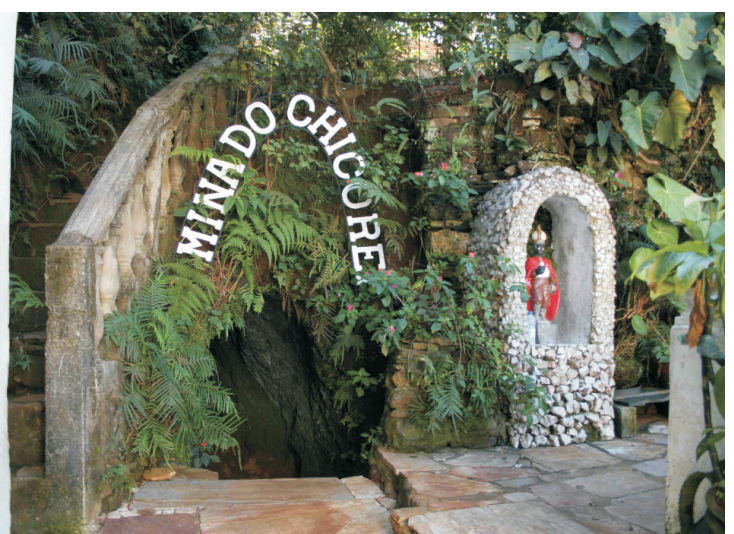

Figura 17 - Entrada da mina de Chico Rei aberta a visitação. Foto: Úrsula Ruchkys de Azevedo.

\subsection{MINA DE PASSAGEM}

Sítio de interesse nacional do ponto de vista científico, educativo, cultural, histórico e turístico. Entre 1729 e 1819, vários mineiros obtiveram concessões para explorar a propriedade mineral de Passagem até que, em 1819 , ela foi adquirida, junto com algumas concessões vizinhas, pelo Barão de Eschwege que criou a primeira companhia mineradora do País de capital privado, com o nome de Sociedade Mineralógica da Passagem. Eschwege modernizou o processo de lavagem e beneficiamento do minério aurífero com a instalação de um engenho com nove pilões e moinhos para pedras, até então desconhecidos no Brasil e estabeleceu o primeiro plano de lavra subterrânea. A Mina da Passagem, atualmente desativada, pertence à Companhia de Minas de Passagem - CMP e está aberta a visitação. A descida para as galerias subterrâneas se faz de através de um trolley, em um plano inclinado que chega a $315 \mathrm{~m}$ de extensão e $120 \mathrm{~m}$ de profundidade (Figura 18).

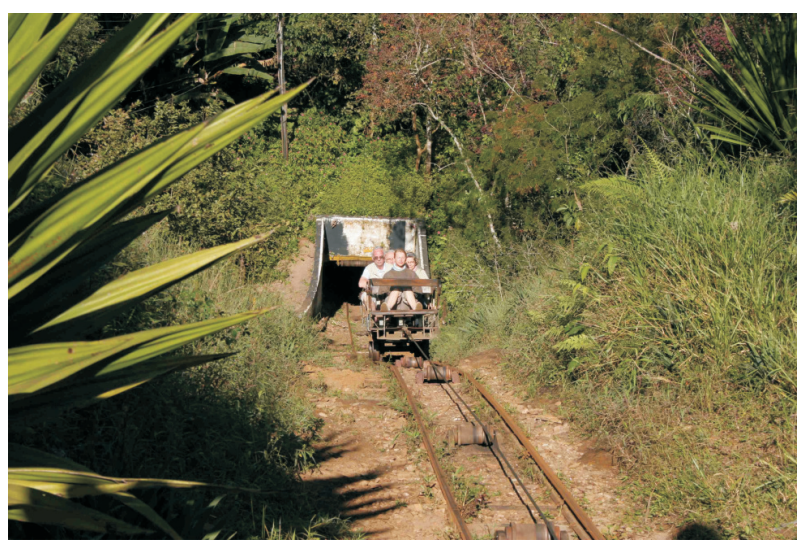

Figura 18 - Entrada da mina da Passagem. Foto: Dionisio Tadeu de Azevedo.

\subsection{MINA DE GONGO SOCO}

Sítio de interesse nacional do ponto de vista educativo, cultural, histórico e turístico. No século XIX a Mina de Gongo Soco viveu seu apogeu com a mineração aurífera subterrânea, mecanizada e industrializada. A mina foi explorada por ingleses da Cornuália, entre 1826 a 1856, que lá criaram uma autêntica vila inglesa, com hospital, capela e cemitério particular (IEPHA, 1995). As ruínas, tombadas pelo IEPHA/MG em 1995, estão localizadas no município de Barão de Cocais, a 76 quilômetros de Belo Horizonte. Com a escassez do rico mineral, a mina ficou paralizada durante muito tempo e, em 1986, a extração do ouro foi substituída pela do ferro, atividade ainda existente no local (Figura 19). 


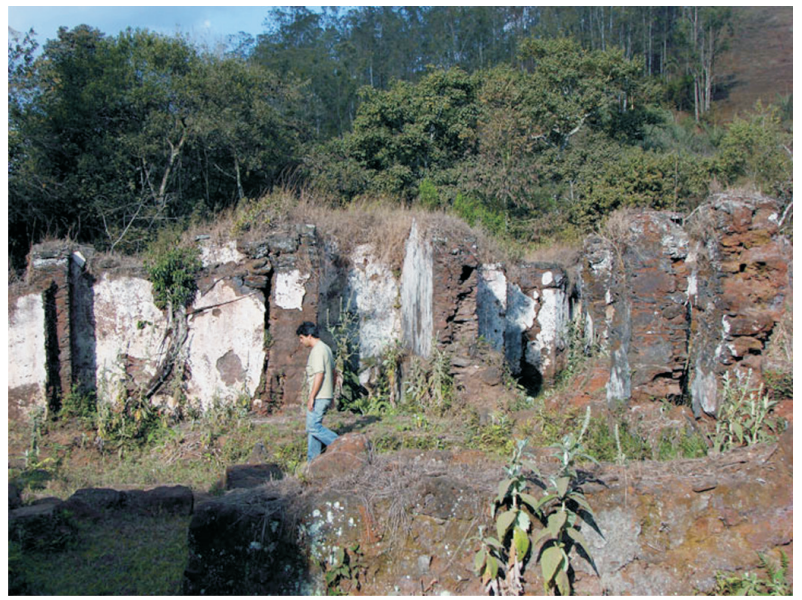

Figura 19-Ruínas da mina de Gongo Soco. Foto: Acervo CPRM.

\subsection{CAPÃO DO LANA}

Sítio de interesse internacional do ponto de vista científico, turístico e histórico. No Brasil, o topázio amarelo foi descoberto por volta de 1760 na região de Ouro Preto, provavelmente em aluviões lavados em busca de ouro. A descoberta de topázios no morro da Saramenha, em 1772, atraiu grande número de mineiros para o local. No século XIX as viagens científicas realizadas por naturalistas europeus no sudeste brasileiro incluiam, invariavelmente, as minas de topázio nos arredores de Ouro Preto, em função do interesse que despertavam. As lavras de topázio do Capão do Lana, na região de Rodrigo Silva, são objeto de observações geológicas no relato da viagem por Minas Gerais, em 1818 , de Spix e Martius e também de Francis de la Porte, o Conde de Castelnau, que lá esteve em 1843 (Machado 2009). A Topázio Imperial Mineração iniciou sua operação em Capão do Lana em 1971, chegando a empregar 80 pessoas. Realizou levantamentos geológicos e pesquisas de seu subsolo, cumprindo todos os requisitos legais. Opera de acordo com planos de lavra aprovados, acompanhados e fiscalizados pelos órgãos oficiais de mineração (Figura 20). Atualmente, com ritmo modesto de produção continua a abastecer grandes indústrias joalheiras.

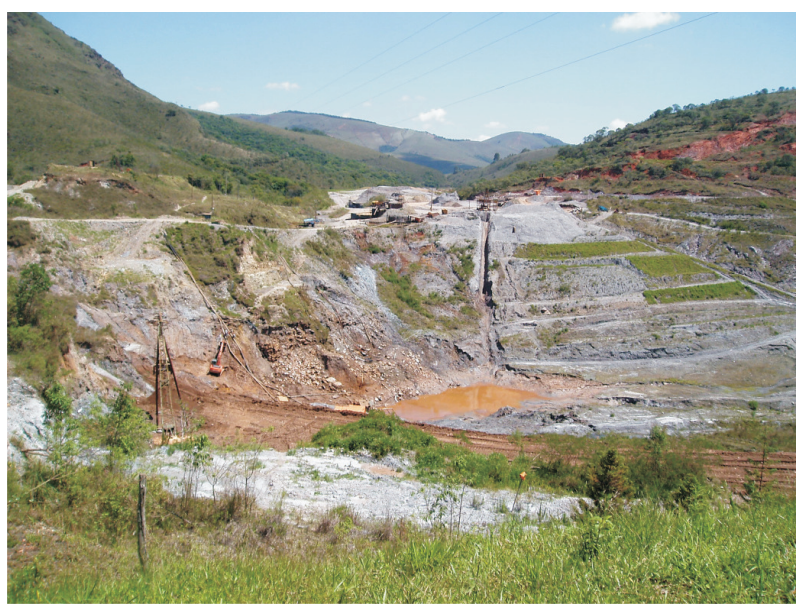

Figura 20 - Vista geral da mina de Capão do Lana. Foto: Maria Márcia Magela Machado.

\subsection{PONTE DO BIQUINHA}

Sítio de interesse nacional do ponto de vista cultural, histórico e turístico. Para evitar o descaminho do ouro entre as minas e o Rio de Janeiro, o governo português determinou que apenas o Caminho Velho e, depois, o Caminho Novo, aberto como alternativa para evitar a rota marítima entre Paraty e o Rio de Janeiro, poderiam ser utilizados para transporte desse bem. Estes caminhos oficiais receberam o nome de Estrada Real. No trecho Ouro Branco - Ouro Preto existem ainda vários vestígios arqueológicos como pontes, bueiros, galerias fluviais e pluviais, contenções, muros de arrimo e restos de piso e é um dos trechos originais mais bem preservados da Estrada Real em Minas Gerais. A Ponte do Biquinha é um destes remanescentes, feita em pedra de cantaria, arco pleno ou romano e parapeitos incompletos do século XIX (Figura 21).

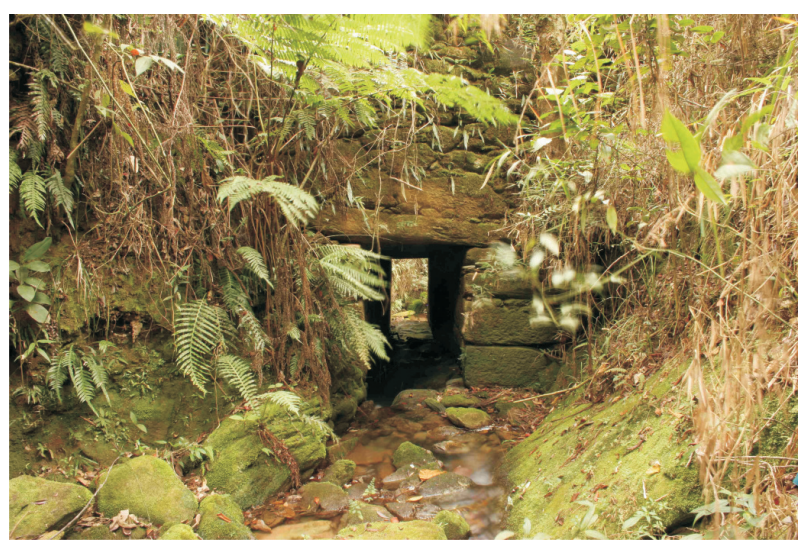

Figura 21 - Vista da ponte do Biquinha em trecho preservado da Estrada Real. Foto: Úrsula Ruchkys de Azevedo. 


\subsection{FAZENDA PÉ DO MORRO}

A Fazenda Pé do Morro foi construída no século XVIII, com todas as paredes em pedras, nas proximidades da Serra de Ouro Branco, daí o seu nome. Serviu como hospedagem para visitantes, atividade que, com o tempo, parece ter ganhado muito importância. Em meados do século XIX teve um acréscimo de pau a pique e sofreu algumas modificações (Figura 22). A origem da fazenda está relacionada à necessidade de abastecimento das sociedades fundadas na base econômica da mineração que se preocuparam muito pouco com a produção de gêneros alimentícios, fato que resultou em várias crises de abastecimento durante o ciclo do ouro. Atualmente é tombada pelo Patrimônio Histórico e funciona como Hotel Fazenda sendo um exemplo vivo de uma imensa riqueza histórica.

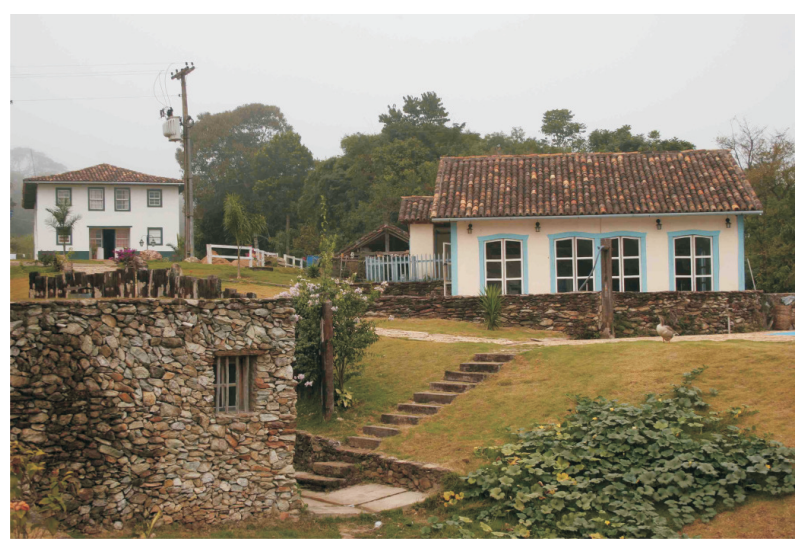

Figura 22 - Vista da Fazenda Pé do Morro. Foto: Úrsula Ruchkys de Azevedo.

\subsection{BICAME DE PEDRAS}

O Bicame de Pedra foi construído em 1792 por Manoel Ferreira Pinto para fornecimento de água para mina de ouro na Serra de Boa Vista. Constitui atração turística da Estrada Real e oferece uma linda vista do Caraça. O muro tem 4 metros de altura com portal em forma de arco romano sobre o qual a água era conduzida para ser utilizada na lavagem de cascalho para lavra de ouro nos séculos XVIII e XIX. Sua construção custou uma arroba (cerca de $15 \mathrm{Kg}$ ) de ouro (Figura 23).

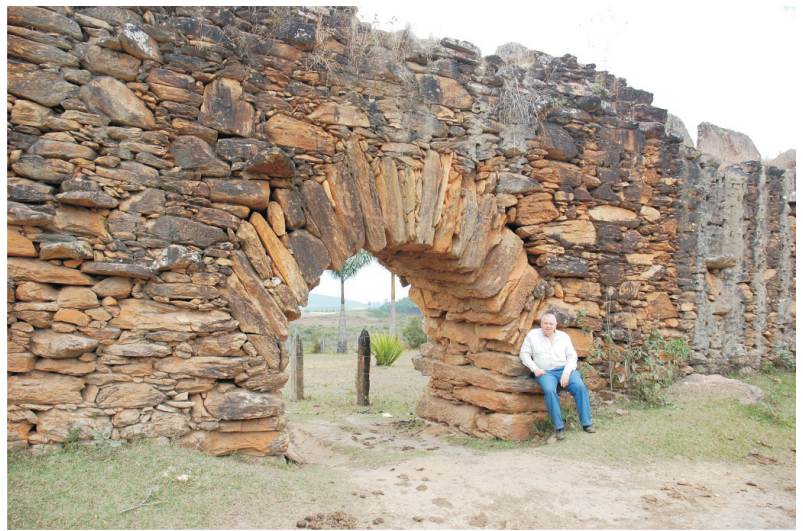

Figura 23 - Aqueduto Bicame de Pedra exibindo portal em arco romano. Foto: Acervo CPRM.

\subsection{PICO DE ITABIRITO}

Sítio de interesse internacional do ponto de vista científico, educativo, estético, cultural, histórico e turístico. Trata-se de um corpo verticalizado de minério de ferro compacto, constituído de óxidos de ferro (hematita e magnetita), de origem hidrotermal, formado durante o evento termotectônico denominado Transamazônico, de idade paleoproterozóica e está inserido na Formação Cauê, Grupo Itabira do Supergrupo Minas (Rosière et al. 2005). O Pico de Itabirito é uma referência histórica e geográfica. Localizado junto à rodovia que liga Belo Horizonte a Ouro Preto, na borda do Sinclinal Moeda, serviu como marco geográfico para os bandeirantes e exploradores do território mineiro nos século XVI e XVII e para os naturalistas viajantes no século XVIII (Figura 24).

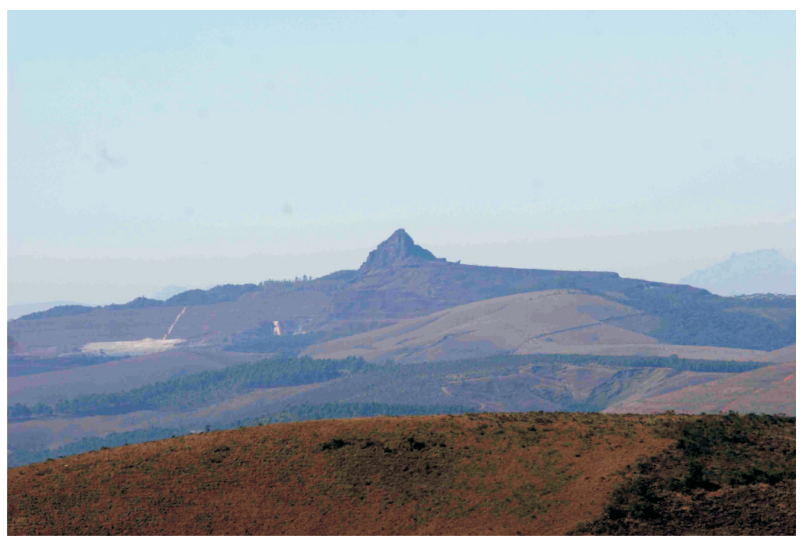

Figura 24 - Vista geral do Pico de Itabirito. Foto: Dionisio Tadeu de Azevedo. 


\section{EXEMPLOS E PROPOSTAS DE VALORIZAÇÃO PATRIMONIAL NO QUADRILÁTERO FERRÍFERO}

O Quadrilátero Ferrífero já foi e é alvo de projetos e propostas de valorização de seu patrimônio geológico e mineiro, sendo neste artigo apresentadas, como exemplos, seis destas propostas: 1) Valorização por percursos geoturísticos-culturais, proposto por Ruchkys et al. (2006); 2) Criação de um Geopark a ser integrado na GGN/UNESCO proposto por Ruchkys (2007); 3) Excursão virtual pelo Quadrilátero Ferrífero, proposto pela CPRM (2007); 4) Descomissionamento da Mina de Gongo Soco, proposto por Neto (2008); 5) Painéis interpretativos de sítios geológicos em um projeto conjunto desenvolvido, em 2012, pela CPRM/UFMG; 6) Valorização pelo geoturismo do Parque Estadual do Itacolomi, proposto por Ostanello (2012).

Ruchkys et al. (2006) propõem a valorização patrimonial do Quadrilátero Ferrífero por meio de três percursos geoturísticos apresentando quatorze pontos de interesse que contemplam os diferentes aspectos que caracterizam esta que é uma das regiões geologicamente e historicamente mais importantes de Minas Gerais. A definição dos percursos geoturísticos buscou organizar e integrar as potencialidades do Quadrilátero Ferrífero. Os percursos auxiliam na organização de segmentos específicos, para atender às demandas também específicas.

Ruchkys (2007) mostra o potencial do Quadrilátero Ferrífero para a criação de um geoparque, a partir da análise dos critérios operacionais da UNESCO para reconhecimento de áreas como geoparques descritos no documento Operational Guideline for National Geoparks seeking UNESCO's assistance. Para isso faz uma seleção de sítios geológicos do Quadrilátero Ferrífero representativos de sua história geoecológica e da história da mineração. A seleção desses sítios está baseada em critérios internacionais e sua descrição segue a recomendação da UNESCO e do SIGEP. Com base nessas recomendações os sítios são descritos mostrando sua importância em termos globais e/ou regionais e são propostas medidas de proteção. A análise dos sítios e dos critérios da UNESCO mostra que a idéia de criação de um geoparque reconhecido pela UNESCO pode ser aplicada ao Quadrilátero Ferrífero, constituindo um instrumento de divulgação e conservação de um exemplo significativo do patrimônio geológico pré-cambriano da Terra e do patrimônio associado à história da mineração do Brasil.

A CPRM disponibilizou em 2007 no site http://www.cprm.gov.br/estrada_real/ o Projeto "Excursão Virtual pela Estrada Real no Quadrilátero Ferrífero. Aspectos geológicos, históricos e turísticos". O projeto teve como objetivo proporcionar a sinergia do conhecimento geocientífico com a história, a economia, a sociologia e o turismo de uma região que surgiu para o país como o berço da própria cidadania nacional desde meados do século XVII. A excursão apresenta um mapa do roteiro com a descrição de pontos de interesse geológico e cultural.

Neto (2008) com base em uma avaliação mínero-geoambiental apresenta como uma das alternativas de plano de fechamento para a mina de Gongo Soco (cuja expansão está projetada para até 2014) uma valorização para uso exclusivo voltado à conservação. Neste contexto o autor sugere a criação de uma unidade de conservação com vistas à implantação de estrutura de pesquisa, divulgação, visitação e educação. Para esta valorização Neto (2008) salienta a importância do resgate do passado e a apropriação da história local pelas antigas e atuais comunidades mineras. Tais proposições poderiam contribuir para o desenvolvimento local, por meio de projetos de conservação, restauro e uso turístico e educativo de antigas minas e demais elementos do patrimônio mineiro, a exemplo do que ocorre em muitas regiões mineiras de diversos países.

Sobre o geoturismo merece destaque o Projeto de Sinalização Interpretativa financiado pelo Serviço Geológico do Brasil (CPRM) em parceira com a Universidade Federal de Minas Gerais e executado pelo Instituto Terra Brasilis. O projeto teve como principal objetivo elaborar e instalar placas com informações geológicas em sítios do Quadrilátero Ferrífero com linguagem acessível, aproximando o cidadão comum de seu patrimônio geológico e promovendo a geoconservação. Na primeira etapa do projeto os sítios contemplados foram: Serra do Rola Moça, Serra da Piedade, Serra do Curral, Gnaisse de Cachoeira do Campo e Pico do Itacolomi. Além de focar a geologia específica de cada sítio geológico as placas também trazem uma informação geral sobre a evolução geológica do Quadrilátero Ferrífero.

Ostanello (2012) faz um reconhecimento e descrição de feições geológicas localizadas ao longo de trilhas do Parque Estadual do Itacolomi e demonstra sua potencialidade geoturística. Como contribuições da pesquisa, foram feitas considerações sobre a inclusão do geoturismo às ações de uso público do Parque. A autora sugere também a inserção dos resultados de sua pesquisa no contexto do Geopark Aspirante Quadrilátero Ferrífero, contribuindo com seus objetivos de divulgação da geologia e desenvolvimento social.

\section{CONSIDERAÇÕES FINAIS}

O Quadrilátero Ferrífero é uma província mineral rica em geossítios e lugares mineiros. O esgotamento dos recursos e consequente encerramento da atividade extrativa no Quadrilátero Ferrífero podem levar a um processo de declínio social, desertificação humana, degradação patrimonial e ambiental como já ocorrido em outras fases da história da mineração neste mesmo território e há muitos exemplos em outros lugares. Neste contexto, propostas associadas à 
valorização do patrimônio geológico e mineiro devem ser desenvolvidas e fomentadas tais como a constituição de circuitos geo-mineiros que valorizam o território como herdeiro de uma história extrativa secular e que promovam as geociências junto ao grande público. Salienta-se ainda que valores patrimoniais na interface entre a geologia e a mineração, cujas atividades se desenvolvem na região desde o ciclo do ouro no Brasil colonial, devem ser também valorizados incluindo o patrimônio imaterial associado. Alguns projetos e propostas já vêm sendo desenvolvidos com este fim e nos últimos anos tem avançado com o inventário do patrimônio geológico e mineiro. No entanto, é importante um levantamento ainda mais detalhado não somente em nível de território - Quadrilátero Ferrífero, mas incluindo um inventário do patrimônio geológico e mineiro de cada município.

\section{Referências}

ABAIDE, J.P, 2012. Os fósseis na constituição federal brasileira. Revista Direito em foco, p. 1-12. Disponível em:http://www.unifia.edu.br/projetorevista/artigos /direito/20121/fosseis_constituicao.pdf

ALKMIM F.F., MARSHAK S. 1998. Transamazonian Orogeny in the Souther São francisco Craton Region, Minas Gerais, Brazil: Evidence for Paleoproterozoic Collision and Collapse in the Quadrilátero Ferrífero. In: Precambrian Res., 90:1-2.

ALKMIM F.F., NOCE C.M. 2006. The paleoproterozoic Record of the São Francisco Craton. In: IGCP 509 Field Workshop, Bahia and Minas Gerais, Brasil. Field guide and Abstracts. UFOP-UFBA, 1:37-73.

BALTAZAR O. F., PEDREIRA A.J. 2000. Associações litofaciológicas. In: Projeto Rio das Velhas - texto explicativo do mapa geológico integrado, escala 1:100.000 (Reimpressão). Belo Horizonte, Ministério de Minas e Energia - Secretaria de Minas e Metalurgia, 43-48 $p$.

CASTRO P.T.A., ENDO I., MAIZATTO J.R., SANTOS M.C., LIPSKI, M. 2001. Depósitos sedimentares cenozóicos do Quadrilátero Ferrífero, Minas Gerais, Brasil. In: Congresso latino-americano de Geologia. Montevidéu. Anais. v.1,11:12-16p.

CASTRO P.T.A., NALINI JÚNIOR H.A., LIMA H. M. 2011. Entendendo a Mineração no Quadrilátero Ferrífero. Ecológico, Belo Horizonte, 93p.

CÉSAR-MENDES J. 2003. Patrimônio geológico/mineiro da região de Ouro Preto. In: VILLAS BOAS R.C.V., ALBULQUERQUE G.de A.S.C. (orgs). Patrimonio geológico y minero en el contexto del cierre de minas. Cetem /Cyted, Rio de Janeiro, 1:111-123p.

CHOAY F. 2001. A Alegoria do patrimônio. UNESP, São Paulo, 282p.

CORDEIRO J.M.L. 2010. Património geomineiro em Portugal. In: COTELO NEIVA J.M., RIBEIRO A., MENDES V., NORONHA F., RAMALHO M. (eds) Ciências Geológicas - Ensino e Investigação e sua História, Porto, II:483-490p.

CPRM - Serviço Geológico do Brasil 2007. Excursão virtual pela Estrada Real no Quadrilátero Ferrífero aspectos geológicos, históricos e turísticos. D i s p o n íve l e m : http://www.cprm.gov.br/estrada_real/. Acessado em 25 de fevereiro de 2013.
GALLEGO E., GARCIA C.A. 1996. Introducción en el patrimônio geológico. Bases para su valorización, protección, conservación y utilización. Ministério de Obras Públicas, Transportes y Médio Ambiente de Espana (MOPTMA). Série Monografias. Madrid, 8793p.

HOSE T.A. 1995. Selling the story of Britain's stone. Environmental Interpretation, 10, 12:16-17.

HOSE T.A. 2000. Geoturismo europeo. Interpretacion geologica y promocion de la conservacion geologica para turistas. In: BARETTINO D., WIMBLEDON W.A.P.

IEPHA. 1995. Projeto Ruínas de Gongo Soco. Relatório Final das Pesquisas Histórica e Arqueológica, Barão de Cocais, v. I.

KING L.C. 1956. A geomorfologia do Brasil oriental. Rev. Bras. Geogr. 18(2):147-265p.

LICCARDO A. 2007. Turismo Mineral em Minas Gerais, Brasil. Revista Global Tourism (Online), 3:01-17p.

MACHADO M. M. M. 2009. Construindo a imagem geológica do Quadrilátero Ferrífero: conceitos e representações. Tese de Doutorado. PósGraduaçãoem Geologia, Departamento de Geologia, Universidade Federal de Minas Gerais, 256p.

MARTINS A.L. 1984. Breve História dos garimpos de ouro no Brasil. In: ROCHA G.A. (org) Em busca do Ouro, garimpos e garimpeiros do Brasil. Marco Zero, São Paulo, 177-222p.

MARTINS R.B. 1989. História da mineração no Brasil. Empresa das Artes, São Paulo, 127p.

MELLO C.L., SANT'ANNA L.G., BERGQVIST L.P. 2002. Fonseca, MG - Vegetais fósseis do Terciário brasileiro. In: SCHOBBENHAUS C., CAMPOS D.A., QUEIROZ E.T., WINGE M., BERBERT-BORN M.L.C. (eds.) Sítios Geológicos e Paleontológicos do Brasil. DNPM/CPRM - Comissão Brasileira de Sítios Geológicos e Paleobiológicos (SIGEP), Brasília, 01:73-79p.

NERY M.A.C., SILVA E.A.da. 2001. O bem mineral. D i s p o ível e m : www.dnpm.gov.br/assets/galeriadocumento/.../our o.pdf. Acessado em 14 de abril de 2013.

NETO S.E. 2008. Avaliação minero-geoambientalda mina de Gongo Soco para fins de descomissionamento: [manuscrito] propostas, 202p. 
OSTANELLO M.C. 2012. O patrimônio geológico do Parque Estadual do Itacolomi (Quadrilátero Ferrífero, MG): análise e inventariação de lugares de interesse geológicos e trilhas geoturísticas. Dissertação de Mestrado. Pós-graduação, Departamento de Geologia, Universidade Federal de Ouro Preto. 204p.

PEDREIRA A.J. 1995. Associações de litofácies do Supergrupo Rio das Velhas. CPRM (Relatório Interno), Salvador, $4 p$.

RENGER F.E., NOCE C.M., ROMANO A.W., MACHADO N. 1994. Evolução sedimentar do Supergrupo Minas: 500 ma. de registro geológico no Quadrilátero Ferrífero, Minas Gerais, Brasil. Geonomos, 2(1):1$11 p$.

RIART O. P. 2000. La conservación del Patrimonio Geológico y Minero. In: Ciento cincuenta años (18491999). Estudio e investigación en Ciencias de la Tierra. Instituto Geológico y Minero de España, Madrid, 73$101 p$.

RODRIGUES J., CARVALHO C.N., CHAMBINO E. 2011. “Há Ouro na Foz!"e outras actividades de divulgação do património geomineiro do Geopark Naturtejo. In: Actas do VI Simpósio sobre mineração e metalurgia históricas no sudoeste europeu, Abrantes, 263-282p.

ROSIÈRE C.A., RENGER F.E., PIUZANA D., SPIER C.A. 2005. Pico de Itabira, MG - Marco estrutural, histórico e geográfico do Quadrilátero Ferrífero. In: WINGE M., SCHOBBENHAUS C., BERBERT-BORN M., QUEIROZ E.T., CAMPOS D.A., SOUZA C.R.G., FERNANDES A.C.S. (eds) Sítios Geológicos e Paleontológicos do Brasil. D i s p o n íve I e $m$ http://sigep.cprm.gov.br/sitio042/sitio042.pdf . Acessado em 20 de fevereiro de 2013.

RUCHKYS U.A, GOMES B.M., SILVA M. F. 2006. Definição de percursos geoturísticos-culturais no Circuito do ouro e estrada real no contexto do Quadrilátero Ferrífero, MG. (Relatório de pesquisa).

RUCHKYS U.A. 2007. Patrimônio geológico e geoconservação no Quadriátero Ferrífero, Minas Gerais: potencial para criação de um geoparque da UNESCO. Tese de Doutorado. Pós-Graduaçãoem Geologia, Departamento de Geologia, Universidade Federal de Minas Gerais, 209p.

RUCHKYS U.A. 2009. Geoparques e a musealização do território: um estudo sobre o Quadrilátero Ferrífero. Geologia USP, Publicação Especial, 5:5-46p.

RUCHKYS U.A, RENGER F. E., NOCE C.M., MACHADO M.M.M. 2009. Serra da Piedade, Minas Gerais: da lenda do Sabarabuçu ao patrimônio histórico, geológico, paisagístico e religioso. In: SCHOBBENHAUS C., CAMPOS D. de A., QUEIROZ E. T. de, WINGE M., BERBERT BORN M. L. (eds) Sítios geológicos e paleontológicos do Brasil. Ministério de Minas e Energia, DNPM, CPRM, SIGEP, Brasília: v. II, 203-212p.
RUCHKYS U.A., MACHADO M.M.M.; CASTRO P.T.A., RENGER F.E., TREVISOL A. 2012.Geoparque Quadrilátero Ferrífero, Minas Gerais. In: SHOBBENHAUS C., SILVA C. (orgs). Geoparques do Brasil: propostas. Serviço Geológico do Brasil, Rio de Janeiro, 1:183-220 p.

SANT'ANNA L.G., SCHORSCHER J.H.D., RICCOMINI C.1997. Cenozoic tectonics of the Fonseca Basin region, Eastern Quadrilátero Ferrífero, MG, Brazil. Journal of South American Earth Sciences, 10(3):275$284 p$.

SILVA F. R. 2007. A paisagem do Quadrilátero Ferrífero, MG: potencial para o uso turístico da sua geologia e geomorfologia. Dissertação de mestrado. Programa de Pós-Graduação em Geografia. Departamento de Geografia. Universidade Federal de Minas Gerais, $144 p$.

SINFERBASE - Sindicato Nacional da Indústria da Extração do Ferro e Metais Básicos. Relatório Anual 2011 Minério de Ferro. Disponível em http://www.sinferbase.com.br/relatorios.php. Acesso em 10 de abril de 2013.
Manuscrito ID 31541

Submetido em abril de 2013 Aceito em junho de 2013 